\title{
GAS CHROMATOGRAPHY-MASS SPECTROSCOPIC ANALYSIS OF BLACK PLUM SEED (SYZYGIUM CUMINI) EXTRACT IN HEXANE
}

\author{
ABDUL JALEEL A $\mathrm{H}^{1}{ }^{1}$, JINAN F MAHDI ${ }^{2}$, MAZHAR FAROOQUI ${ }^{3}$, SHAIKH Y H $^{4^{*}}$ \\ ${ }^{1}$ Department of Maulana Azad College of Arts, Science and Commerce, Aurangabad, Maharashtra, India. ${ }^{2}$ Department of \\ Techniques College of Electrical and Electronic Engineering, Techniques Middle Technical University, Baghdad, Iraq. ${ }^{3}$ Department of \\ Dr. Rafiq Zakaria College for Women, Aurangabad, Maharashtra, India. ${ }^{4}$ Department of Shivaji College, Kannad, Aurangabad, \\ Maharashtra, India. Email: shaikhyh@gmail.com
}

Received: 07 September 2018, Revised and Accepted: 18 October 2018

\section{ABSTRACT}

Objective: Black plum seed has unique medicinal value and used as antidiabetics, antibacterial, and anti-inflammatory.

Methods: Gas chromatography-mass spectrometry (GC-MS) analysis of the extracts of black plum seed obtained using solvent extraction with hexane as a solvent is used to attempt the identification of prominent components.

Results: Black plum seed extract is obtained by solvent extraction technique using Soxhlet extractor. A total of 10 compounds are predicted in black plum seed extract by GC-MS analysis.

Conclusion: The work presented relates to the study of GC-MS analysis of the extract of black plum seed obtained using solvent extraction with hexane as a solvent. Of ten compounds of black plum seed extract, five compounds are known to have antimicrobial properties.

Keywords: Gas chromatography-mass spectrometry, Black plum, Syzygium cumini, Seed extract.

(C) 2019 The Authors. Published by Innovare Academic Sciences Pvt Ltd. This is an open access article under the CC BY license (http://creativecommons. org/licenses/by/4. 0/) DOI: http://dx.doi.org/10.22159/ajpcr.2019.v12i2.29396

\section{INTRODUCTION}

Black plum's scientific name is Syzygium cumini, in India, and it is commonly known as Jamun. The tree is a commonly present in India and other tropical and subtropical regions of the world. Black plum tree has a great economic value because most of the parts of the tree such as the fruit, leaves, bark, and seeds are used as medicine to treat various diseases. For example, it is used to manage the blood sugar level in the patients suffering from diabetes. There are reports of study conducted to study the effects of various concentrations $(0.0,1.56,3.125,6.25$, $12.5,25,50$, and $100 \mu \mathrm{g} / \mathrm{ml}$ ) of the leaf extract of $S$. cumini Linn or Eugenia cumini (black plum, Jamun, family: Myrtaceae) on the alteration in the radiation-induced micronuclei formation in the cultured human peripheral blood lymphocytes [1].

Analysis of the antioxidant activity of the fruit skin using different assays, such as hydroxyl radical-scavenging assay, based on the benzoic acid hydroxylation method, superoxide radical-scavenging assay, based on photochemical reduction of nitro blue tetrazolium (NBT) in the presence of a riboflavin-light-NBT system, 2,2-diphenyl-1-picrylhydrazyl radicalscavenging assay, and lipid peroxidation assay using egg yolk as the lipid-rich source confirms the antioxidant activity [2]. Characterized and evaluation of anthocyanin pigments from $S$. cumini fruit peels for their antioxidant efficacy, and stability as extract and in formulation is also reported [3], and the study identified three anthocyanins as gluco glucosides of delphinidin, petunidin, and malvidin by high-performance liquid chromatography (HPLC)-ESI-MS. Gas chromatography-mass spectrometry (GC-MS) technique is one of the effective techniques in a study related to medicinal properties and antibacterial properties of herbal extracts [4]. For the extraction of volatile components from the black plum fruits by simultaneous distillation and solvent extraction method, modified Likens and Nickerson apparatus can be used, and the analysis of volatile compounds by GC-MS showed the presence of 30 compounds [5]. There are studies conducted to deal with the downstream processing of anthocyanins from black plum
(S. cumini L.) to obtain anthocyanins in a purified form [6], this study includes adsorption employing six different adsorbents, and among these, Amberlite XAD7HP showed the highest adsorption capacity $(1.07 \mathrm{mg} / \mathrm{mL}$ of adsorbent) and desorption ratio $(87.62 \%)$.

Chemoprotective activity of black plum seed extract against in vivo oxidative stress and genomic is also established [7]. There are studies, showing that black plum seed extract can possibly play a vital role as a chemopreventive agent against oxidative stress and genomic damage [7]. Black plum seed kernel extracts exhibit the inhibition of $\alpha$-glucosidase from mammalian (rat intestine), bacterial (Bacillus stearothermophilus), and yeast (Saccharomyces cerevisiae, Baker's yeast). The in vitro studies using the mammalian $\alpha$-glucosidase from rat intestine indicated the extracts to be more effective in inhibiting maltase when compared to the acarbose control [8], and other techniques such as HPLC and nuclear magnetic resonance are also useful in the identification of constituents of extract [9].

In recent times, we used supercritical fluid extraction technology (instrument name: SFC L-tex Japan) to extract the compounds from various biological materials such as plants and animals, performed GCMS analysis of oil extracted for freshwater crab, and also analyzed fatty acid composition of some animals [10-16].

\section{METHODS}

Black plum seed powder is purchased from local market of Aurangabad city, Maharashtra, India. Black plum seed powder is subjected to Soxhlet extraction process using hexane as a solvent to obtain black palm seed extract.

GC-MS is a unique method for the analysis and measures the quantity of organic volatile and semi-volatile compounds. GS is employed to separate mixtures into individual components employing a temperature-controlled capillary column. MS is applied to recognize a 


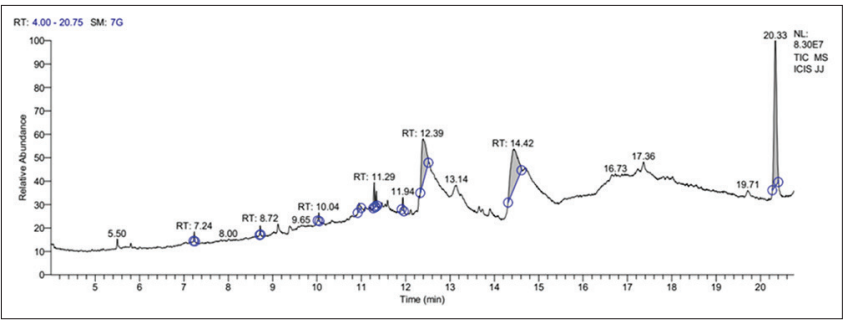

Fig. 1: Gas chromatography mass spectrometry analysis spectrum of black plum seed extract

Table 1: Specification of GC-MS

\begin{tabular}{ll}
\hline Conditions during GC-MS analysis & \\
\hline Runtime $(\mathrm{min})$ & 54.09 \\
Injection volume $(\mu \mathrm{l})$ & 1.00 \\
Scans & 6439 \\
Low mass $(\mathrm{m} / \mathrm{z})$ & 40 \\
High mass $(\mathrm{m} / \mathrm{z})$ & 400 \\
Gas & Helium \\
Solvent & Hexane \\
\hline GC-MS: Gas chromatography-mass spectrometry
\end{tabular}

GC-MS: Gas chromatography-mass spectrometry variety of components from their mass spectra. In the present study, black plum seed powder is used for extraction and analysis to study the constituents. Black plum seed extract is extracted by solvent extraction technique using Soxhlet extractor with hexane as a solvent. The GC-MS analysis is carried out at SAIF, Chandigarh University. The operating conditions used in the GC-MS analysis are given in Table 1.

\section{RESULTS AND DISCUSSION}

The GC-MS chromatography of black plum seed extract shows different peaks (Fig. 1). Each peak is representing a constituent present in the extract. These peaks are further analyzed and the fractions. So obtained, at different retention time is characterized by MS, which is represented in Fig. 2 .

GC-MS analysis of black plum seed extract reveals that the seed contains 10 different compounds. Table 2 shows that, among all compounds, compound with retention time 20.33 shows highest concentration (39.98\%), followed by compound with retention time 14.42 (30.28\%), compound with retention time 12.39 (20.30\%), compound with retention time $11.29(2.61 \%)$, compound with retention time 10.95 (1.63\%), compound with retention time 11.34 (1.49\%), and compound with retention time 11.94 (1.45\%), and concentrations of remaining compounds are $<1 \%$. These are probable compounds based on GC-MS compound library search.

Table 2: (a) probable compounds present in black plum seed extract

\begin{tabular}{|c|c|c|c|c|c|c|}
\hline Compound name & Area \% & $\begin{array}{l}\text { Molecular } \\
\text { formula }\end{array}$ & $\begin{array}{l}\text { Molecular } \\
\text { weight }\end{array}$ & RT (min) & Peak area & Structure \\
\hline Oleic acid & 30.28 & $\mathrm{C}_{18} \mathrm{H}_{34} \mathrm{O}_{2}$ & 282 & 14.42 & 155781647.79 & \\
\hline n-hexadecanoic acid & 20.30 & $\mathrm{C}_{16} \mathrm{H}_{32} \mathrm{O}_{2}$ & 256 & 12.39 & 104407935.16 & \\
\hline Cyclooctasiloxane, hexadecamethyl & 0.79 & $\mathrm{C}_{16} \mathrm{H}_{48} \mathrm{O}_{8} \mathrm{Si}_{8}$ & 593.2315 & 10.04 & 4076063.86 & \\
\hline $\begin{array}{l}\text { 1-monolinoleoylglycerol trimethylsilyl } \\
\text { ether }\end{array}$ & 1.45 & $\mathrm{C}_{27} \mathrm{H}_{54} \mathrm{O}_{4} \mathrm{Si}_{2}$ & 498 & 11.94 & 7461639.22 & \\
\hline $\begin{array}{l}\text { Octadecanal, 2-bromo- } \\
\text { Cyclohexasiloxane, dodecamethyl- }\end{array}$ & $\begin{array}{l}2.61 \\
0.79\end{array}$ & $\begin{array}{l}\mathrm{C}_{18} \mathrm{H}_{35} \mathrm{BrO} \\
\mathrm{C}_{12} \mathrm{H}_{36} \mathrm{O}_{6} \mathrm{Si}_{6}\end{array}$ & $\begin{array}{l}346 \\
444.924\end{array}$ & $\begin{array}{l}11.29 \\
7.24\end{array}$ & $\begin{array}{l}13411130.27 \\
4081565.85\end{array}$ & \\
\hline Cycloheptasiloxane, tetradecamethyl- & 0.69 & $\mathrm{C}_{14} \mathrm{H}_{42} \mathrm{O}_{7} \mathrm{Si}_{7}$ & 519.078 & 8.72 & 3531066.64 & \\
\hline $\begin{array}{l}\text { Pyrazole[4,5-b] imidazole, } \\
\text { 1-formyl-3-ethyl-6-á-d-ribofuranosyl- }\end{array}$ & 1.63 & $\mathrm{C}_{12} \mathrm{H}_{16} \mathrm{~N}_{4} \mathrm{O}_{5}$ & 296.283 & 10.95 & 8380945.03 & \\
\hline Stearic acid, 3-(octadecyloxy) propyl ester & 1.49 & $\mathrm{C}_{39} \mathrm{H}_{78} \mathrm{O}_{3}$ & 595.05 & 11.34 & 7641092.59 & \\
\hline Benzaldehyde, 2,4,5-trimethoxy- & 39.98 & $\mathrm{C}_{10} \mathrm{H}_{12} \mathrm{O}_{4}$ & 196.2 & 20.33 & 205642953.61 & \\
\hline
\end{tabular}




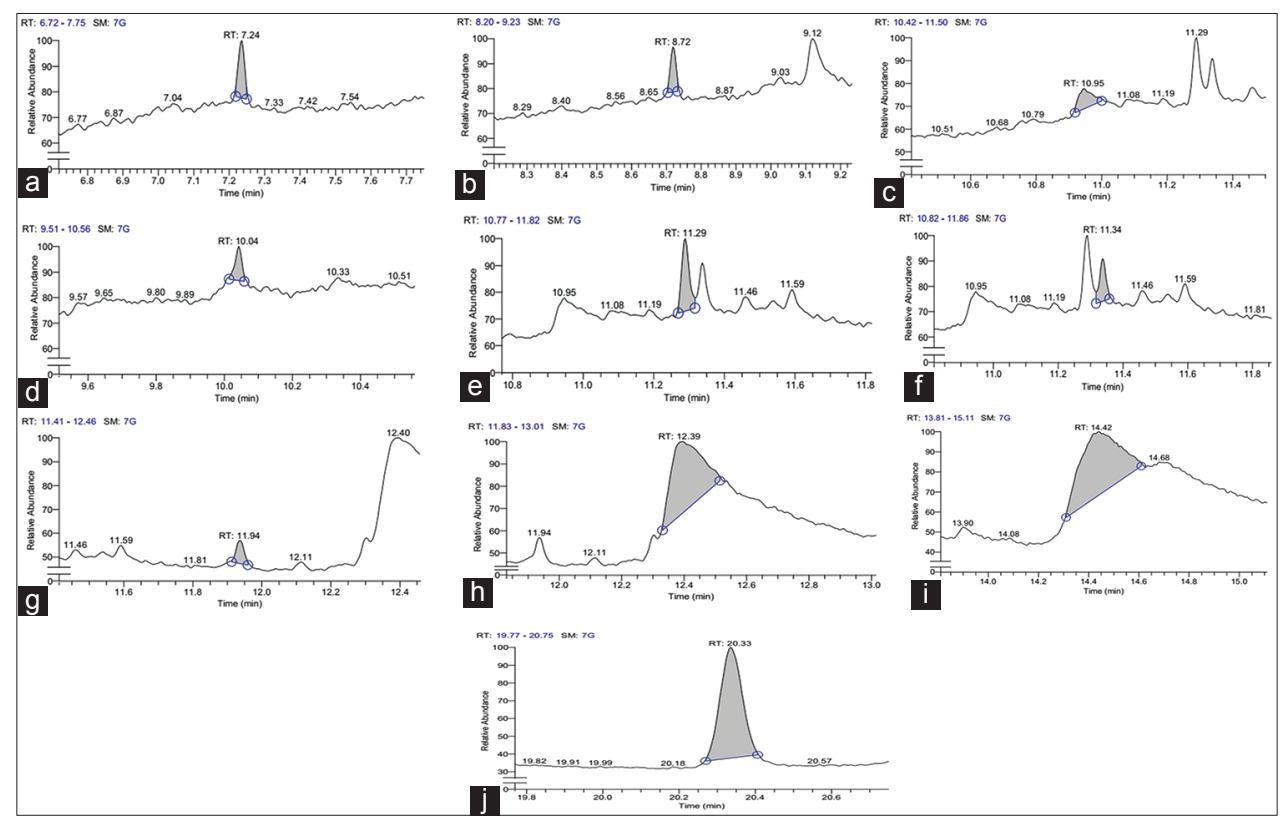

Fig. 2: Prominent peaks of gas chromatography-mass spectrometry of black plum seed extract, (a) spectrum with retention time $=7.24$, (b) spectrum with retention time $=8.72$, (c) spectrum with retention time $=10.04$, (d) spectrum with retention time $=10.95$, (e) spectrum with retention time $=11.29$, (f) spectrum with retention time $=11.34,(\mathrm{~g})$ spectrum with retention time $=11.94$, (h) spectrum with retention time $=12.39$, (i) spectrum with retention time $=14.42$, (j) spectrum with retention time $=20.33$

Table 2: (b) Antimicrobial activity of few compounds of black plum seed extract

\begin{tabular}{|c|c|c|}
\hline S. no & Compound name & Reported bioactivity \\
\hline 1 & Oleic acid & Antimicrobial \\
\hline 2 & n-hexadecanoic acid & $\begin{array}{l}\text { Anti-inflammatory, Antioxidant, hypocholesterolemic nematicide, pesticide, anti-androgenic } \\
\text { flavor, hemolytic, 5-Alpha reductase inhibitor, potent mosquito larvicide }\end{array}$ \\
\hline 3 & Cyclooctasiloxane, hexadecamethyl & Conditioning agent \\
\hline 4 & 1-Monolinoleoylglycerol trimethylsilyl ether & Antimicrobial Antioxidant, Anti-inflammatory antiarthritic, antiasthma, diuretic \\
\hline 5 & Octadecanal, 2-bromo- & Nontoxic and efficient anti-microbial agents \\
\hline
\end{tabular}

Black plum seed extract contains 10 different compounds. From these ten compounds, 5 compounds possess antimicrobial properties. Oleic acid possesses antimicrobial property [17]. n-hexadecanoic acid possesses following properties: Anti-inflammatory, antioxidant, hypocholesterolemic nematicide, pesticide, anti-androgenic flavor, hemolytic, 5-alpha-reductase inhibitor, and potent mosquito larvicide [17]. Cyclooctasiloxane and hexadecamethyl are used as conditioning agent [18]. 1-monolinoleoylglycerol trimethylsilyl ether possesses following properties: Antimicrobial, antioxidant, antiinflammatory, antiarthritic, antiasthma, and diuretic [19]. Octadecanal, 2-bromo- is non-toxic and efficient antimicrobial agent [20].

\section{CONCLUSION}

The work presented relates to the study of GC-MS analysis of the extracts of black plum seed obtained using solvent extraction with hexane as a solvent. The extract is found to contain many medicinally active compounds. Ten compounds are identified and details presented, five of which are found to exhibit antimicrobial activity against different diseases. The medicinally active compounds can be isolated and considered for the preparation of medicine.

\section{ACKNOWLEDGMENT}

One of the authors is thankful to UGC, Delhi, for provision of grants for carrying out this research work under the MANF scheme.

\section{AUTHORS' CONTRIBUTIONS}

All authors have equally contributed at all stages of the work except extraction; extraction was done by Abdul Jaleel A. H under the supervision of Dr. Yusuf Haneef Shaikh. Analysis of chromatography report was done with the help of Dr. Mazhar Farooqui.

\section{CONFLICTS OF INTEREST}

The author hereby declares no conflict of interest regarding the manuscript and experimentation done.

\section{REFERENCES}

1. Jagetia GC, Baliga MS. Syzygium cumini (Jamun) reduces the radiation-induced DNA damage in the cultured human peripheral blood lymphocytes: A preliminary study. Toxicol Lett 2002;132:19-25.

2. Banerjee A, Nabasree D, De B. In vitro study of antioxidant activity of Syzygium cumini fruit. Food Chem 2005;90:727-33

3. Veigasa JM, Narayan MS, Laxman PM, Neelwarne B. Chemical nature, stability and bioefficacies of anthocyanins from fruit peel of Syzygium cumini Skeels. Food Chem 2007;105:619-27.

4. Derwich E, Benziane Z, Chabir R, Taouil R. In vitro antibacterial and GC/MS analysis of the essential oil, extract of leaves of Rosmarinus officinalis grown in morocco. Int J Pharm Pharm Sci 2011;3:89-95.

5. Vijayanand P, Rao LJ, Narasimham P. Volatile flavour components of jamun fruit (Syzygium cumini L). Flavour Fragr J 2018;33:

6. Jampani C, Aduja N, Raghavarao KS. Purification of anthocyanins from jamun (Syzygium cumini L.) employing adsorption. Sep Purif Technol 2014:125:170-8

7. Arun R, Prakash MV, Abraham SK, Premkumar K. Role of Syzygium cumini seed extract in the chemoprevention of in vivo genomic damage and oxidative stress. J Ethnopharmacol 2011;134:329-33.

8. Shinde J, Taldone T, Barletta M, Kunaparaju N, Hu B, Kumar S, et al. Alpha-glucosidase inhibitory activity of Syzygium cumini (Linn.) skeels seed kernel in vitro and in goto-kakizaki (GK) rats. Carbohydr Res 2008;343:1278-81 
9. Painuli S, Rai N, Kumar N. GC-MS analysis of methanolic extract of leaves of rhododendron campanulatum. Int J Pharm Pharm Sci 2015;7:299-303.

10. Moghal MM, Pradhan V, Ladniya V. Fatty acid composition of oil extracted from freshwater edible crab (Barytelphusa cunicularis). Res J Pharm Biol Chem Sci 2015;6:542-7.

11. Basaar O, Saeedi AA, Fatema S, Mohsin M, Farooqui M. Supercritical fluid extraction of oil from freshwater edible crab (Barytelphusa cunicularis). J Med Chem Drug Disc 2015;2015:285-9.

12. Moghal MM, Pradhan V, Ladniya V. Supercritical fluid extraction of oil from freshwater edible crab (Barytelphusa cunicularis). Res J Pharm Biol Chem Sci 2016;7:1182-6

13. Pradhan V, Moghal MM, Ladniya V, Fatema S. Supercritical fluid extraction: Applications to biological system. Res J Pharm Biol Chem Sci 2015;6:371-8.

14. Ladniya V, Pradhan V, Moghal MM. Fatty acid composition of oil extracted from magur fish (Clarias batrachus). J Med Chem Drug Discov 2016;1:504-10

15. Moghal MM, Ladniya V, Pradhan V. Gas chromatography-mass spectroscopy analysis of oil extracted from freshwater edible crab (Barytelphusa cunicularis). Res J Pharm Biol Chem Sci 2016;7:1840-7.

16. Ladniya V, Moghal MM, Pradhan V. Fatty acid composition of oil extracted from surmai fish (Scomberomorus commerson) from Marathwada region. Res J Pharm Biol Chem Sci 2017;8:299-304.

17. Abubakar MN, Majinda RR. GC-MS analysis and preliminary antimicrobial activity of Albizia adianthifolia (Schumach) and Pterocarpus angolensis (DC). Medicines (Basel) 2016;3:E3

18. Jayashree I, Geetha DH, Rajeswari M. Gc-Ms analysis of bioactive constituents of Glochidion ellipticum WT. Int J Pharm Sci Res 2015;6:2546-50.

19. Parthipan B, Suky MG, Mohan VR GC-MS analysis of phytocomponents in Pleiospermium alatum (Wall. ex Wight \& Arn.) Swingle, (Rutaceae). J Pharmacogn Phytochem 2015;4:216-22.

20. Hussein HM. Analysis of trace heavy metals and volatile chemical compounds of Lepidium sativum using atomic absorption spectroscopy, gas chromatography-mass spectrometric and fourier-transform infrared spectroscopy. Res J Pharm Biol Chem Sci 2016;7:2529-55. 